\title{
Beyond the Myth of the 'Good Italian'. Recent Trends in the Study of the Italian Occupation of Southeastern Europe during the Second World War
}

\begin{abstract}
This article surveys the existing literature on the occupation policy Italy conducted in Southeastern Europe during the Second World War. The whole subject was largely neglected by scholars of contemporary Italian history up to the 1990s, but in the last twenty years a consistent flow of studies has begun to appear. The reasons for the previous disregard of the topic and, now, the growing interest in it are investigated in the first part of this article. The second part focuses on work done in recent years. It evaluates the strengths and weaknesses of this new literature, and maps out a series of a blank spots that should be addressed by future research.
\end{abstract}

Paolo Fonzi is a Gerda Henkel Research Fellow at the Department of History at the Humboldt University in Berlin.

\section{An Almost Forgotten Past (1945-1990)}

Amazing as it may seem almost seventy years after the end of the war, the Italian occupation ${ }^{1}$ of the Balkan countries between 1941 and 1943 is still a much under-researched topic. This is, first and foremost, due to the extreme delay with which the subject started to come to the attention of Italian historians. As I detail below, the first comprehensive study on Italian occupation policies during the Second World War, Davide Rodogno's Il nuovo ordine mediterraneo, was published as late as 2003, and this was a revised version of a young author's dissertation. ${ }^{2}$ The lack of interest in the subject shown by Italian historians is particularly

${ }^{1}$ For brevity's sake, I use the term 'occupation' to refer to all forms of rule established by the Italians. Viewed from the perspective of international law, however, they fall within different categories: purely military occupation (Greece and parts of the Croatian territory), personal union (Albania), governorship (Montenegro, Dalmatia), and annexation (Province of Ljubljana, Kosovo).

2 Davide Rodogno, Il nuovo ordine mediterraneo. Le politiche di occupazione dell'Italia fascista in Europa, Torino 2003 (Engl. translation, Fascism's European Empire. Italian Occupation During the Second World War, Cambridge 2006). 
surprising if one considers that the experience of occupation shaped the life of many Italians and affected Italian postwar society significantly. In September 1943, approximately 650,000 Italian soldiers - half of the Italian troops stationed outside Italy in World War II - were garrisoned in several regions of Southeastern Europe, and to this figure we should add the civil personnel employed in administration and the many Italians - soldiers' relatives, for example - whose lives were indirectly influenced by the process of occupation. ${ }^{3}$

Not surprisingly, then, enquiry into the reasons why this experience did not find its way into scholarship or into the collective memory of Italians for so many years has become a historiographical subject of its own. ${ }^{4}$ Historians have attributed responsibility for this huge case of amnesia to a conscious strategy of denial propagated by Italy's postwar elites. In a recent, widely acclaimed book, the Italian historian Filippo Focardi has shown how the myth of the 'good Italian', and its counterpart, the myth of the 'bad German', were established by the Italian elites after 1943 as a self-acquitting master narrative to downplay culpability for events during the Second World War. ${ }^{5}$ According to this narrative, the policy of the Italian occupiers had been extremely benevolent, due to their 'mild' or 'Mediterranean' national character. As in many other European countries, the harshness of occupation by the Germans in the last phase of the war swayed Italian public opinion towards a strong sense of victimization. Italians projected their own responsibility onto the outsider and used this to obliterate memory of Fascism's aggressive policy on their own side of the Axis. ${ }^{6}$ This 'retroactive de-fascistisation', as Emilio Gentile has expressively called it, ${ }^{7}$ has affected historiographic scholarship, which has consistently privileged the years following the armistice with the Allies in September 1943, and within this frame, has focused overwhelmingly on the Italian resistance. A telling instance is the fact that an entire bookshelf of studies exists on the massacre of the Acqui

3 In the same period, approximately two million soldiers were stationed in Italy proper, cf. Giorgio Rochat, Le guerre italiane. Dall'impero d'Etiopia alla disfatta 1935-1943, Torino $2005,322$.

4 Unfortunately, there has been no attempt to investigate whether, in the postwar years, memory of occupation was kept alive in private or small-range communications such as local newspapers. An example of how productive such an investigation might be is offered by the project of oral interviews on 'the Holocaust in family memory' conducted in Germany, cf. Sabine Moller / Karoline Tschuggnall / Harald Welzer, eds, Opa war kein Nazi. Nationalsozialismus und Holocaust im Familiengedächtnis, Frankfurt/M. 2002.

5 Filippo Focardi, Il cattivo tedesco e il bravo italiano. La rimozione delle colpe della seconda guerra mondiale, Roma, Bari 2013.

6 A recent study based on private correspondence and memoirs has shown how many Italians supported imperialist policy under Fascism, cf. Mario Avagliano / Marco Palmieri, Vincere e vinceremo! Gli italiani al fronte 1940-1943, Bologna 2014.

7 Emilio Gentile, Fascismo. Storia e interpretazione, Bari 2002, VII. 
Division by the Wehrmacht on the islands of Cefalonia and Corfu in $1943,{ }^{8}$ while we still have practically no reliable information on the occupation of the islands by the very same division between 1941 and 1943.

Interestingly, individual memory of the war assumes a very similar pattern. In most accounts published by war veterans, events after 8 September 1943which for many meant a long period of internment in German camps-almost completely overshadow any memory of the previous period. To be sure, a sense of having been victimized is no Italian peculiarity, but is a common characteristic of many war veterans' accounts. As Thomas Kühne and Benjamin Ziemann have noted, war experience is often narrated by soldiers as a 'history of suffering' - one that systematically downplays individual agency and responsibility for the unfolding of violence. ${ }^{9}$ In Italy such sanitized memory patterns received a strong legitimization from above.

A second reason for the unwillingness of the Italians to deal with this part of their past is that the memory of the war has been strongly obfuscated by a feeling of shame, and indeed still is. From a military point of view, Italy's prestige as a great power and pride in the Italian army as the embodiment of the nation were undermined by a series of bad performances during the years 1940-43. Having started the war as an equal partner of Germany, entitled to develop its own imperial policy, the catastrophic performance of the Italian army on many fronts turned the 'parallel war', as Mussolini had bombastically named it, into a 'subaltern war': Italy became a minor partner of the Third Reich. ${ }^{10}$ The

${ }^{8}$ A recent publication, summarizing the most relevant studies in the field is Camillo Brezzi, ed, Né eroi, né martiri, soltanto soldati. La Divisione 'Acqui' a Cefalonia e Corfù: settembre 1943, Bologna 2014. Another telling example is the fact that Hermann Frank Meyer's study on the 1st Mountain Division, which addresses all crimes this division committed (not just the massacre of the Italians), has been translated in an abridged version under the title 'The massacre of Cefalonia and the 1st German Mountain Division', cf. Hermann Frank Meyer, Il massacro di Cefalonia e la $1^{\circ}$ divisione da montagna tedesca, Udine 2013. The German original is Hermann Frank Meyer, Blutiges Edelweiß. Die 1. Gebirgs-Division im Zweiten Weltkrieg, Berlin 2007.

9 Thomas Kühne/Benjamin Ziemann, Militärgeschichte in der Erweiterung. Konjunkturen, Interpretationen, Konzepte, in: Thomas Kühne / Benjamin Ziemann, eds, Was ist Militärgeschichte?, Paderborn 2000, 9-46.

${ }_{10}$ Malte König, Kooperation als Machtkampf. Das faschistische Achsenbündnis BerlinRom im Krieg 1940/41, Köln 2007. The war against Greece as an awkward lieu de mémoire is dealt with in Giorgio Rochat, La guerra di Grecia, in: Mario Isnenghi, ed, I luoghi della memoria. Simboli e miti dell'Italia unita, Roma, Bari 1997, 347-363. To get a sense of the feeling of marginalization experienced by members of the military in postwar Italy, cf. Giulio Mellini, Rivalutiamo l'esercito. L'esercito italiano nella seconda guerra mondiale, Bologna 1948. Guri Schwarz has analysed how the military lost the monopoly of interpretation of the war experience after 1945 and how this influenced the memory of the war. Cf. Chapter Two 'Pacificazione e democratizzazione: dal collasso dello Stato alla nascita della repubblica antifascista', in: Guri Schwarz / Marco Mondini, Dalla guerra alla pace. Retoriche e pratiche della smobilitazione nell'Italia del Novecento, Verona 2007, 117-229. 
creation of the Italian empire, thus, started at the very moment at which Italian foreign policy had lost much of its autonomy. This has prevented Italians from having the 'positive', apolitical military remembrance of the war, imbued with a sense of military prowess and national pride, that has been able to flourish in other countries. ${ }^{11}$

Lack of academically sound scholarship on the subject from the immediate postwar years to the 1960s has resulted in a memory of the Italian occupation that has been strongly influenced by exculpating political agendas. In those years, historical writing about the Second World War was dominated by accounts written by its protagonists, mostly high ranking officers who had held leading offices in the occupation administration, such as Mario Roatta. ${ }^{12}$ These accounts played a key role in consolidating the myth of the 'good Italian'. They portrayed the bloody repression practised by the Italian authorities as simply a response to the brutality of the partisans. In the 1960s this situation changed slightly, thanks to the activity of scholars working within, or in collaboration with, the network of Institutes for the History of the Resistance Movement, such as Teodoro Sala and Enzo Collotti. Still based on a relatively tiny base of sources, a number of essays on the Italian occupation policy in Yugoslavia appeared in this context. ${ }^{13}$ Sala and Collotti took a convinced antifascist and procommunist stance, and thus their studies had a strong moral commitment to denounce the aggressive Fascist imperialist policy. Moreover they tried to establish bridges between Italian and Yugoslav historians and between Italian and Yugoslav perspectives on the Second World War. ${ }^{14}$

In the same years, but from a very different standpoint, the Historical Office of the Italian Army published several monographs on the role played by Italy in the Second World War, and in this framework a number of studies on Italian occupation policies appeared. These studies, too, dealt almost exclusively with Yugoslavia. They were mostly based on a very traditional military historical approach, and focused massively on the activities of the Italian army in the

11 Such a positive, depoliticized memory of the war has, for example, persisted in the German veteran association. See the considerations in Konrad Köstlin, Erzählen vom Krieg Krieg als Reise, Bios. Zeitschrift für Biographieforschung und Oral History 2, no. 2 (1989), 173-182.

${ }^{12}$ For an overview of the first accounts of occupation in Yugoslavia, see Eric Gobetti, L'occupazione italiana in Jugoslavia (1941-1943). Storiografia e memoria pubblica, Passato e Presente 87 (2012), 39-53. As for Albania, the self-apologetic account by the former Italian governor (Luogotenente Generale) there has been highly influential: Francesco Jacomoni di San Savino, La politica dell'Italia in Albania, Rocca San Casciano 1965.

13 Enzo Collotti / Teodoro Sala / Giorgio Vaccarino, L'Italia nell'Europa danubiana durante la seconda guerra mondiale, Monza 1967; Enzo Collotti / Teodoro Sala, Le potenze dell'asse e la Jugoslavia. Saggi e documenti 1941/1943, Milano 1974; Teodoro Sala, Il fascismo italiano e gli Slavi del sud, Trieste 2008.

14 Massimo Pacetti, ed, L'imperialismo italiano e la Jugoslavia, atti del convegno italojugoslavo, Ancona 14-16 ottobre 1977, Urbino 1978. 
occupied regions. The title of a book published in 1978 by the Army's Historical Branch, 'The operations of Italian military units in Yugoslavia' written by Salvatore Loi, gives a clear idea of how narrow the approach of these studies was. ${ }^{15}$ Most of these books were based on painstaking archival research, as the historians, who worked for the army-mostly officers themselves - had privileged access to the sources stored in the military archives. One of the main threads in this literature was to counter the widespread assumption that the Italian army had been weak and ineffective during the war and the occupation. Once again these publications stressed the reassuring myth that the Italian army had been relatively benign, very seldom guilty of war crimes, and if, then only in response to much worse atrocities committed by the partisans. At the end of his massive study on Yugoslavia, for example, Loi included a short chapter dealing with the lawfulness of the reprisals conducted by the Italians, and he concluded that they were only the 'symmetrical response to preceding criminal acts committed by the enemy'. ${ }^{16}$

The intense debates on the antifascist legacy in Italian politics sparked by De Felice's studies on Fascism ${ }^{17}$ and Claudio Pavone's interpretation of the resistance as a civil war ${ }^{18}$ did not address occupation policy as a part of the history of Italy during the Second World War period. Although Pavone's enormously influential study did much to de-mythicize the image of Italian resistance activities as a war of the entire nation against the invader, acknowledging the willing support many Italians gave to the Fascist cause after 1943, it did not immediately spark any interest in the history of occupation. In the volume covering the Second World War in his massive Mussolini biography, Renzo de Felice devoted only 20 pages to the occupation, and did so only to throw light on the development of the alliance between Berlin and Rome. ${ }^{19}$ Finally, it should be noted that, unlike the German occupation of Europe, the Italian case has attracted only sparse interest within international historiography. An exception to this is the hotly debated issue of the rescue of the Jews in the occupied territories. This debate has revolved around the question as to whether the Italian authorities saved the Jews out of humanitarian concerns or whether it was, rather, political inter-

\footnotetext{
15 Salvatore Loi, Le operazioni delle unità italiane in Jugoslavia (1941-1943), Roma 1978.

16 Loi, Le operazioni, 256.

17 For an overview on the debate on De Felice's theses cf. Tommaso Baris / Alessio Gagliardi, Le controversie sul Fascismo degli anni 60' e 70', Studi Storici 55, no.1 (2014), 317-333.

18 Claudio Pavone, Una guerra civile. Saggio storico sulla moralità nella Resistenza, Torino 1991.

19 Renzo De Felice, Mussolini l'alleato 1940-1945, Torino 1990, 423-441.
} 
est at play. ${ }^{20}$ Last but not least, only a few significant studies published in the formerly occupied countries have been translated into Italian. ${ }^{21}$

\section{Growing Attention to Fascist Italy's Empire-Building}

It is no surprise, then, that Rodogno's book 'Italy's Mediterranean Empire', published in 2003, was welcomed so enthusiastically by the academic community. ${ }^{22}$ It was the first comprehensive study of Italian occupation policies in Yugoslavia, Greece, Albania, and France during the Second World War. The path-breaking research in this book opened the way for a younger generation of historians to publish works dealing with the occupation of specific countries.

Several factors led to this change. First, attempts made by some historians, and more particularly the popular media, to minimize the repressive nature of fascism and partially rehabilitate it sparked a heated discussion both in academia and amongst the wider public. This in turn led many scholars to investigate the more repressive activities of the Fascist regime, one of which was clearly the forced occupation of foreign countries. Secondly, in their endeavours to undermine the antifascist consensus in Italy, right-wing political forces placed a massive stress on the foibe massacres in Istria and Dalmatia and the exodus of Italians from those places after the war, leading to the establishment of a National Memorial Day, the so called Giorno del Ricordo, in 2004. This attracted renewed attention to the issue of the Eastern border in Italy's history, ${ }^{23}$ and prompted historians working on the relations between Italy and the Slav-speaking area to extend their interest to the years during which Yugoslavia was occupied. International events fuelled this interest further, in particular the Yugoslav wars of the 1990s which brought the Balkan peninsula into the limelight. Last

${ }^{20}$ For the first view: Jonathan Steinberg, All or Nothing. The Axis and the Holocaust, 1941-1943, London 1990; for the second: Davide Rodogno, 'Italiani brava gente?' Fascist Italy's Policy toward the Jews in the Balkans, April 1941-July 1943, European History Quarterly 35, no. 2 (2005), 213-240.

${ }^{21}$ For example, Tone Ferenc, La provincia 'italiana' di Lubiana: documenti 1941-1942, Udine 1994; Tone Ferenc, 'Si ammazza troppo poco.' Condannati a morte, ostaggi, passati per le armi nella provincia di Lubiana, 1941-1943. Documenti, Ljubljana 1999.

22 Reviewing the Italian edition, MacGregor Knox wrote: 'Il nuovo ordine mediterraneo is a massive, systematic, and largely successful assault on that received wisdom [i. e. the Italiani brava gente myth]. Rodogno's book derives from deep digging in hitherto almost inaccessible Italian army and Foreign Ministry files [...]. [The book] offers a generally persuasive and sustained analysis of little-known, poorly understood, yet vitally important chapters in the history of Fascist Italy and of the war that it willed-and in which it duly perished.' Cf. MacGregor Knox, Review of 'D. Rodogno "Il nuovo ordine mediterraneo"', Journal of Modern History 76, no. 4 (2004), 976-978.

23 Marina Cattaruzza, L'Italia e il confine orientale 1866-2006, Bologna 2007. Recently, the book was translated into English, including an update on the most recent decade: Italy and Its Eastern Border, 1866-2016, New York, London 2017. 
but not least, since 1990 Italian sources have become much more accessible to historians. In that year, the Historical Branches of the Army, Navy and Air Force became subject to general legislation on access to archives. As a consequence, most of the sources previously kept uncatalogued by modern archival criteria were put in order with the help of specialized staff. ${ }^{24} \mathrm{~A}$ period of relatively free access to these sources ensued. Unfortunately, in the last few years, renewed restrictions have been imposed, partially due to lack of resources..$^{25}$

In the following section, I review some of the most relevant results, and also some of the shortcomings of the recent trends in studies on Italy's occupation policies. Subsequently, I touch on some possible ways to overcome the shortcomings I have pinpointed.

\section{Rodogno's 'Italy's Mediterranean Empire'}

In 2003 Davide Rodogno presented an overview of Italian policy in all the regions the country occupied. In its focus, his book was strongly influenced by questions regarding the nature of Italian Fascism which were being heavily debated at the time it was written. Should Fascism be considered a form of totalitarianism or not? Could the transnational category of fascism be applied to the Italian case ${ }^{26}$ Following on from this, at the very beginning of his book, Rodogno asked if the phenomenon of Italian occupation fell under the category of empire, or of empire-building. Drawing on the literature on the Roman Empire, he considered a central feature of any empire to be centralization of power and the existence of a definite political leadership. Basically, this remained the focus of the book, which sought to demonstrate that Fascism had an imperial drive and that the reality of occupation, even when it contradicted Rome's plans, was largely shaped by central plans nonetheless. This drew out comparisons with national socialism. Rodogno sought to demonstrate that, like Germany, Italy had developed plans to conquer its own 'vital space' or Lebensraum, which would be centred on the Mediterranean. 'There is a distinctive feature,' Rodogno wrote, 'shared by the Fascist and Nazi regimes which evinces the close kinship (but not identity) between the two ideologies and the two regimes. I refer to the conquest of living space - of an empire - as an essential component of a totalitar-

24 The 1990 decree confirmed by law instructions that had been issued by the Ministry of Defence in 1979, cf. Silvia Trani, Il Regio esercito e i suoi archivi. Una storia di tutela e salvaguardia della memoria contemporanea, Roma 2013, 530. From the 1970s onwards the Historical Branch of the Army had made its records accessible to a restricted number of external researchers. Access was still granted upon discretionary decision of the military administration. Specialized personnel were employed in all three branches only in the 1990s.

25 Silvia Trani (with Pier Paolo Battistelli), The Italian Military Records of the Second World War, War in History 17, no. 3 (2010), 333-351.

${ }^{26}$ Cf. Gentile, Fascismo. 
ian project to transform society. ${ }^{27}$ To sum up, in Rodogno's interpretation, two aspects are pivotal: occupation as a policy massively influenced by a totalitarian project; and the similarity between Fascist ambitions and those of the Nazis in their empire-building.

As one of its most important contributions, the book brought to light a huge mass of primary sources that had never been used before. As mentioned, many relevant records were made available to a larger public in the 1990s, and Rodogno made extensive use of the records of the military units employed in the occupied areas and the records of the Italian Ministry of Foreign Affairs. Thus Rodogno's work can also be appreciated as a first comprehensive mapping of these sources. If this is one of the merits of the book, it is at the same time one of its limitations: Rodogno did not make use of any sources from countries other than Italy. However, his work did, for the first time, provide a clear overview of the structure of the occupation administrations in different regions. In addition, it dwelt on aspects of the Italian occupations largely neglected up to then, such as the relation between military and civil powers - the civil governors appointed by Mussolini in Dalmatia, Slovenia, and the Ionian and Cyclades Islands - the differences between annexed and formally independent but now occupied regions, and the interplay between the centre and the periphery in decision-making. Rodogno also included in his account the small, less studied occupied territories, such as the Greek islands in the Aegean Sea. His book contains interesting chapters in which, taking a modern grassroots approach, he deals with ordinary soldiers' experiences and investigates the mentality and self-perception of the Italian army and the cohesion within it.

However, one of the consequences of his interpretation of Fascism as a form of totalitarianism, and a consequence also of the sources he used, was that his focus was on the centre of the Italian empire rather than on the peripheries. To be sure, Rodogno did not neglect the interaction between Rome's planning and the reality of occupation, which had to be administered by the men on the spot. Even from the records of the Italian army alone-for example the historical logs kept by small military units-one can see beyond a purely occupier-centred analysis and grasp how local societies reacted to occupation. Moreover, Rodogno was very well aware that the contradictions between planning and actual occupation were huge, and he took this aspect into account. The theoretical tool he employed to frame this contradiction and to explain the interplay between the centre and the practices of the local authorities was an application of Ian Kershaw's concept 'Working towards the Führer' to the Italian case: local administrators were 'Working towards the Duce'. Although Rome's hand was unable to reach its outposts and direct them significantly, leaving the local authorities

27 Rodogno, Fascism's European Empire, 44. 
with considerable room for manoeuvre, local officials, both military and civil (where these last were appointed) were, Rodogno argues, fully committed to fulfilling the will of Mussolini.

As a consequence, in spite of his attempt to a give full account of the complexity of the occupation system, poised as it was between centripetal and centrifugal forces, Rodogno often overestimates the efficacy of planning. A short but telling example is the case of the Cyclades Islands, to which Rodogno devotes some pages of his book. A recent microhistorical study of the Island of Syros under Italian occupation, undertaken by Sheila Lecoeur, focuses on the policy of the two Italian governors of the Cyclades during the occupation of Greece. ${ }^{28}$ Lecoeur's information mostly comes from the records of the local Italian administration, stored in the historical archives of Ermoupolis in Syros. Contrary to Rodogno's account, Lecoeur shows convincingly how far the Italian governors departed from pursuing a planned imperialistic policy. A political middle-term plan was elaborated, the policy of so-called distacco (detachment), which aimed to detach the Cyclades from the mainland and attach them to the Italian colony of the Dodecanese. However, the policy of the governors was far more materially shaped by concerns arising from the dire effects of economic crisis and the need to administer the islands. In this case, therefore, the concept of 'Working towards the Duce' does not help explain the interaction between centre and periphery. Study of the interplay between local society and the local authorities has a stronger explanatory value.

The comparison of Italian Fascism with nazism in Rodogno's book has a political and moralistic undertone. By placing Fascism in the same analytic box as Hitler's creed, he seeks to stress that Fascism should not be 'banalized', but should rather be seen as akin to the 'absolute evil'. ${ }^{29}$ This is a commendable endeavour in itself, as the myth of the 'good Italian' is still widespread in Italian public opinion; but it has misled many Italian historians, especially those of the left, into downplaying the complexity of the history of the societies that were occupied.

Moreover, it is very doubtful whether Ian Kershaw's analytic tool 'Working towards the Führer' can be used in conjunction with the concept of totalitarianism. Kershaw explicitly proposed it as an alternative to the latter. He saw in the concept a feature peculiar to the Third Reich, a dynamic of radicalization

28 Sheila Lecoeur, Mussolini's Greek Island. Fascism and the Italian Occupation of Syros in World War II, London 2009.

${ }^{29}$ It is worth remembering that the argument concerning the different natures of Italian Fascism and German national socialism was one of the main, and most criticized, theses put forward by Renzo De Felice. 
from below deriving from 'the undermining and collapse of what one might call "rational" structures of rule', ${ }^{30}$ rather than an ideological guideline.

This problematic aspect of Rodogno's work - shared by many studies that have followed-derives, I am convinced, from a distorted reception of the historiography of the Third Reich. Scholarship on Nazi Germany from the 1970s onwards, for example the structuralist approach and the more recent Volksgemeinschaft current represented by Michael Wildt, have clearly moved away from a top-down perspective. ${ }^{31}$ But it is the latter that remains implicit in the totalitarianism approach. Moreover, a recent trend in the study of Nazi policy in Eastern Europe, especially in the field of Holocaust studies, is to move beyond intentionalist approaches and to embrace a perspective that stresses the multidirectionality of extreme violence, which is seen as a complex social phenomenon implying a large array of actors and motivations, not as a coherent chain of events originating from planning or intent. ${ }^{32}$ Much Italian historiography seems to remain attached to an old and outmoded interpretation of nazism. It still employs the concept of totalitarianism in order to counter attempts by revisionist historians to downplay the criminal or repressive policies carried out by the Fascist regime.

\section{Recent Studies on Italian Occupation}

The weaknesses I have highlighted in Rodogno's study do not lessen its significance as a pioneering work. Besides being itself an insightful, well-written monument of research, Fascism's European Empire paved the way for the development of academically sound scholarship on Italian occupation policy in the Balkans. ${ }^{33}$ In the last twenty years, the topic has become an established field of research in Italy. The generational factor still plays a key role, as even today this

30 Ian Kershaw, 'Working Towards the Führer'. Reflections on the Nature of the Hitler Dictatorship, Contemporary European History 2, no. 2 (1993), 103-118, 104.

31 For the structuralist approach see the classic work Gerhard Hirschfeld / Lothar Kettenacker, eds, Der 'Führerstaat'. Mythos und Realität. Studien zur Struktur und Politik des Dritten Reiches, Stuttgart 1981. For the Volksgemeinschaft approach, see Martina Steber / Bernhard Gotto, eds, Visions of Community in Nazi Germany, Oxford 2014.

32 See Christian Gerlach's critique of the concept of genocide, Christian Gerlach, Extremely Violent Societies. An Alternative to the Concept of Genocide, Journal of Genocide Research 84, no. 4 (2006), 455-471. An application of this concept to the case of Yugoslavia during World War Two is Alexander Korb, Im Schatten des Weltkrieges. Massengewalt der Ustaša gegen Serben, Juden und Roma 1941-1945, Hamburg 2013.

33 Given the regional focus of this article, I do not deal with the Italian occupation of parts of France, which Rodogno did include in his study. A recent publication, adopting a grassroots perspective is Emanuele Sica, Mussolini's Army in the French Riviera. Italy's Occupation of France, Urbana, Chicago, Springfield 2016. 
field is occupied mostly by junior scholars, often in the stage of their doctoral dissertations.

The literature published in the last twenty years focuses on a series of discrete subjects. A central place is given to the issue of Italian war crimes. ${ }^{34}$ In the last ten years, considerable numbers of studies have appeared in Italy detailing the way Italian war criminals escaped prosecution by Libyan, Ethiopian, Yugoslav, Greek, and Albanian tribunals after the war. ${ }^{35}$ As one can easily imagine, this subject has sparked animated public discussion, prompting many Italian scholars to investigate anew the war crimes committed during occupation. So, for example, in a number of articles Lidia Santarelli has examined the repressive policy practised by the Italian army in Greece. ${ }^{36}$ In particular, she has dealt with the massacre of the entire male population of the village of Domenikon in Thessaly carried out in February 1943. The massacre had been mentioned in some publications but had never been studied in detail and with the use of Italian sources. ${ }^{37}$ Santarelli's study has decisively thrown into question the traditional image of the Sagapò Army - the idea, which the British were already propagating during the war, that the Italian soldiers stationed on Greek territory had had a rather peaceful coexistence with the native population, engaging in intimate relationships with the women. ${ }^{38}$ Basing her work on Italian military sources,

34 A recent overview can be found in Alberto Stramaccioni, Crimini di guerra. Storia e memoria del caso italiano, Bari 2016.

${ }^{35}$ Filippo Focardi, La questione della punizione dei criminali di guerra in Italia dopo la fine del secondo conflitto mondiale, Quellen und Forschungen aus italienischen Archiven und Bibliotheken 80 (2000), 543-624; Filippo Focardi / Lutz Klinkhammer, La questione dei 'criminali di guerra' italiani e una commissione di inchiesta dimenticata, Contemporanea 4, no. 3 (2001), 497-528; Davide Conti, Criminali di guerra italiani: accuse, processi e impunità nel secondo dopoguerra, Roma 2011.

36 Lidia Santarelli, La violenza taciuta. I crimini degli italiani nella Grecia occupata, in: Luca Baldissara / Paolo Pezzino, eds, Crimini e memorie di guerra. Violenze contro le popolazioni e politiche del ricordo, Napoli 2004, 271-291; Lidia Santarelli, Muted Violence. Italian War Crimes in Occupied Greece, Journal of Modern Italian Studies 9, no. 3 (2004), 280-299; cf. also Lidia Santarelli, Fra coabitazione e conflitto. Invasione italiana e popolazione civile nella Grecia occupata. Primavera - estate 1941, Qualestoria 30, no. 1 (2002), 143-155. Besides Santarelli's articles, see the essay by the Director of the Historical Branch of the Army's Archives Lieutenant Colonel Filippo Cappellano, L'occupazione italiana della Grecia (1941-43), Nuova Storia Contemporanea 12, no. 4 (2008), 19-46.

37 Hagen Fleischer, Im Kreuzschatten der Mächte: Griechenland 1941-1944 (Okkupation - Resistance - Kollaboration), Frankfurt/M. et al. 1986. Cf. also the early Greek publication, Iannis E. Gotsis, Floges ston Olympo, Athens 1945, 21-28. The massacre of Domenikon has been the subject of a documentary entitled 'La guerra sporca di Mussolini' (Mussolini's Dirty War) directed by Giovanni Donfrancesco with the assistance of Lidia Santarelli. The documentary has had a wide impact, especially since being broadcast by 'History Channel' in 2008.

${ }^{38}$ It is difficult to trace this stereotyped perception back to its origins and see how its role in the construction of the war memory both in Italy and Greece (where the myth of the Sagapò army is as strong and widespread as in Italy) started up. The existence of a considerable number of cases of intimate relations between Greek women and Italian soldiers, quite often leading 
Lidia Santarelli could show for the first time that the violent acts committed by the Italians were part of a policy consciously planned and ordered by the Italian military authorities in Greece, in particular by General Carlo Geloso. In February 1943, for example, an official letter was issued by Geloso giving directives for the fight against the partisans. This document, according to Santarelli, is 'one of the most significant documents in the process of planning and organizing the military violence that characterized the Italian policy of repression in the occupied territories' ${ }^{\prime 39}$ Geloso's directives made no distinction between partisans and civilians. Thus, along with other documented instances mentioned in Santarelli's article, this source proves that the indiscriminate killing carried out by Italian soldiers was part of a policy of brutalization initiated from above.

Amedeo Osti Guerrazzi comes to very similar conclusions in a recent publication on Slovenia. ${ }^{40}$ Among the territories occupied by the Italians, Slovenia stands out for the extreme violence with which the Italian Royal Army repressed the resistance. Drawing on a considerable number of Italian military sources, Osti Guerrazzi examines whether it was a case of what he calls 'hot violence' - violence developing on the battlefield with a strong situational element-or 'cold violence', planned by the higher ranks of the army and then carried out by the men they commanded. Osti Guerrazzi answers that the propensity to violence was systematically induced by the higher authorities of the army by means of indoctrination of the troops. It was not the war itself that led to forms of brutalization, but the peculiarities of the fascist struggle with its strong ideologization based on a racist worldview. Inspired by scholarly debates on the conduct of the Wehrmacht during the war, especially by Omer Bartov's studies, the book aims to show that Italian military forces were part and parcel of the regime and seeks to demystify the narrative of the 'clean Italian army'. ${ }^{41}$

Recent studies published by the Historical Office of the Italian Army have broadened their approach and deal with the occupational setting as a whole, rather than just with the army itself. So, for example, the scope of some of the

to marriages, is supported by direct evidence, cf. Marco Clementi, Camice nere sull' Acropoli. L'occupazione italiana della Grecia (1941-1943), Roma 2013, 343. We do not know, however, what cultural processes enabled the Sagapò myth to establish itself as the Greek version of the more general myth of the Italian as a benign occupier. It would be interesting to unravel what collective experiences and feelings merged into this strongly gendered form of recalling the occupation period, and worth some in-depth research.

39 Santarelli, Muted Violence, 291.

40 Amedeo Osti Guerrazzi, L'esercito italiano in Slovenia 1941-1943. Strategie di repressione antipartigiana, Roma 2011 (Engl. translation, The Italian Army in Slovenia. Strategies of Antipartisan Repression, 1941-1943, Basingstoke 2013).

${ }_{41}$ The book is influenced by Osti Guerrazzi's participation in a German research group that worked on British and American transcripts of German war prisoners' conversations. Harald Welzer / Sönke Neitzel, eds, 'Der Führer war wieder viel zu human, viel zu gefühlvoll.' Der Zweite Weltkrieg aus der Sicht deutscher und italienischer Soldaten, Frankfurt/M. 2011. 
more recent publications has departed from outdated traditional military history and stretches out to other issues, such as military collaboration and the occupation system as a whole. ${ }^{42}$ However, in these studies there is still a tendency to disregard foreign sources and even foreign secondary literature, and this inevitably results in a strong Italocentric approach.

Regarding the issue of the war crimes themselves, no consensus has yet been reached. The scholarship surrounding them is still divided between the conclusions of two opposing factions. Though not denying the repressive policy practised by the military in the occupied territories, historians attached to the Historical Office of the Army continue to stress the 'reactive nature' of the excesses committed. They downplay the army's responsibility for the brutal treatment of civilians and captured partisans. A recent publication on the Italian occupation of Croatia, for example, affirms in the introduction to a chapter on war crimes that "most historians agree that the Italian violence was, in essence, a "reactive" and not a "preventive" one, as [...] were the German and the Croatian [Ustasha] ones' ${ }^{43}$ As already shown in discussion of Amedeo Osti Guerrazzi and Lidia Santarelli, anti-revisionist historians take a different stance. They highlight the responsibility the higher military ranks had for the immoral and illegal conduct of the army, showing that the officers' corps had been thoroughly 'fascistized' at the onset of the war and how it acted accordingly. Many such historians give strong weight to the much-discussed Circular 3C, a booklet issued by General Mario Roatta in March 1942, which contains instructions for the conduct of troops engaged in antipartisan warfare. In this text, Roatta, then Commander of the Second Army garrisoned in regions of Yugoslavia, clearly expressed his will to transform his feeble Italian soldiers into men motivated by a 'steely determination to destroy the enemy'. ${ }^{44}$

Thus, what has remained contentious is the degree to which Italian armed forces were 'fascistized' during the Fascist era and committed crimes following this ideology. Those who maintain that Italy had an imperialistic drive and committed war crimes are opposed to those who hold that the army behaved correctly during the war and even mitigated Mussolini's aggressive bid for expansion. Both sides of the debate refer back to their own political agendas. However, in light of what recent historians have uncovered, it is untenable to affirm that the Italian army did not consistently support Fascism's imperialis-

42 Marco Cuzzi, L'occupazione italiana della Slovenia (1941-1943), Roma 1998; Alberto Becherelli / Paolo Formiconi, La quinta sponda. Una storia dell'occupazione italiana della Croazia, 1941-1943, Roma 2015.

${ }^{43}$ Becherelli / Formiconi, La quinta sponda, 202.

44 James H. Burgwyn, General Roatta's War against the Partisans in Yugoslavia: 1942, Journal of Modern Italian Studies 9, no. 3 (2004), 314-329, here 317. The same author has made an overview of the Italian occupation of Yugoslavia, James H. Burgwyn, Empire on the Adriatic. Mussolini's Conquest of Yugoslavia, 1941-1943, New York 2005. 
tic drive. Moreover, today, the myth of the Resistenza, created by the political centre-left after the war, is the butt of bitter criticism from leftist historians as well, since it has contributed greatly to the self-acquitting myth that allowed the Italian Fascist experience to be swept under the carpet.

In recent years, a feeling of dissatisfaction has been growing among historians over the excessive centrality the war crimes issue has taken in studies of the occupation. So, for example, in the introduction to his monograph on the Italian occupation of Greece-the first comprehensive study of the subject published in Italy-Marco Clementi states that, when he undertook his research in 2009, he felt that existing scholarship on the Italian occupation in the Balkans was obsessed with uncovering war crimes. ${ }^{45}$ His own research aim, by contrast, was to shed light on 'occupational everyday life': he was interested in the 'normality' of the occupation, rather than the exceptional occurrences of resistance and counterinsurgency. Based on Greek and Italian sources, his book devotes a chapter to describing the terrible famine that hit Greece, and it has several sections on Italian policy in different areas of the country such as the Ionian Islands and the Cyclades, where Italian civil governors were appointed, and the Dodecanese, which had been under semi-colonial rule from Italy since 1912. Finally, the last chapters of the book narrate the story of Italo-Greek relations between September 1943 and the Peace Treaty of 1947.

Several other scholars from the younger generation have gone beyond the archives of the occupiers and, increasingly, have taken into account sources from the occupied countries themselves. Remarkable in this respect is the work of Eric Gobetti, who has focused his research on the Italian occupation of Yugoslavia, using both Italian and Yugoslav records. Not primarily a historian of Fascism, Gobetti does not adopt an Italocentric view, but takes into account the dynamics of the occupied society. While one of Gobetti's monographs focuses on Croatia, a second provides an overview of all the areas of Yugoslavia that were occupied by Italy, albeit in different juridical forms (annexation, bogus independence, military occupation). ${ }^{46}$ Among the many themes he deals with in his books, Gobetti examines the reasons behind the alliances the Italian authorities made in Yugoslavia, especially the alliance with the Serbian Chetniks in occupied Croatia and Montenegro. As is well known, the initial pro-Croatian policy of the Italians was soon replaced by a broad system of alliances with other ethnic groups, concentrating on Serb collaboration. Gobetti stresses the purely military

45 Clementi, Camicie nere sull' Acropoli.

46 On Croatia, Eric Gobetti, L'occupazione allegra. Gli italiani in Jugoslavia (1941-1943), Roma 2007; on Yugoslavia, Eric Gobetti, Alleati del nemico. L'occupazione italiana in Jugoslavia (1941-1943), Roma, Bari 2013. The author has devoted other essays to related subjects, for example, Eric Gobetti, Dittatore per caso. Un piccolo duce protetto dall'Italia fascista, Napoli 2001; Eric Gobetti, L'occupazione italiana in Montenegro. I principali nodi storiografici, Italia Contemporanea 260 (2010), 475-493. 
rationale for this choice, and the fact that the decision to shift alliance from the Croats to the Serbs was taken by the men on the spot-principally the military commanders of the Italian troops in Yugoslavia. Only after the event was this decision sanctioned by the politicians in Rome. Gobetti's studies show that in Yugoslavia, as in all the territories occupied by Italy, the balance of power shifted increasingly to the military after the first months of occupation, and it was the men on the spot who subsequently determined most of the policies adopted.

Gobetti's conclusions about the policratic nature of power structures throughout occupied Yugoslavia and the shift of power towards the military authorities are confirmed by a recent study by Federico Goddi. ${ }^{47}$ Goddi's monograph is an in-depth scrutiny of a relatively tiny region, Montenegro, which the Italians tried to turn into a puppet state. This project was dropped after the uprising of July 1941, and a military governership instated. Goddi's study broadens the picture of what occupation entailed, giving considerable weight to hitherto less-explored aspects. Basing his work on a large selection of Italian and Montenegrin sources, he shows that the Italian authorities failed to provide the new political bodies they had established with economic self-sufficiency. Through lack of a proper decision-making process and because they envisaged a customs and monetary union of all their occupied regions (though it was never implemented), the Italians gave priority to political considerations. Thus, to give but one example, when drawing up the borders of the Protectorate of Montenegro, they decided to annex the Ulcinj region to Albania. This was part of a project to realize a 'Greater Albania'; but, by detaching Ulcinj from Montenegro the Italians undermined the local economy, which was based on salt extracted from the Ulcinj mines. As Goddi illustrates, the contradictions within the Italian occupation policy laid the foundations of its own failure from the very beginning. Indeed, the revolt of July 1941, traditionally ascribed exclusively to political grievances, is explained by Goddi with reference to the hardships the population was suffering in a blighted economic situation. A further innovative aspect of Goddi's study is its focus on the activities of the Italian military justice system in occupied Montenegro, encompassing not only the Military Tribunal in Cetinje but also extraordinary military tribunals which single military units were allowed to set up. Goddi painstakingly details what these tribunals did, imposing harsh sentences on opponents - though, contrary to a common view in the Montenegrin historiography, death sentences were relatively few - and exercising a sort of micro-repression against the local population, inflicting a large number of minor sentences that impacted on the population's everyday life.

A more traditional line of study with a different kind of focus is diplomatic history. Heavily based on diplomatic sources, a number of studies analyse the

\footnotetext{
47 Federico Goddi, Fronte Montenegro. L'occupazione militare italiana 1941-1943, Gorizia
} 2016. 
relations between Italy and the independent state of Croatia. ${ }^{48}$ Italian policy in the regions of Kosovo attached to Albania in 1941 has been examined in the same way. ${ }^{49}$ These studies provide valuable insights, but they rarely reach beyond the investigation of interstate relations.

\section{Research Lacunae}

After twenty years of research, we have a much clearer picture of Italian occupation policy than we did in the 1990s, and many of the shortcomings of the first research studies have been overcome. Nevertheless there are still many blank spots that, in my opinion, need to be filled.

This need applies, in the first place, to regions yet to get their share of attention. Most of the studies on Italian occupation have focused on Yugoslavia; only a few have dealt with Greece, and still fewer have tackled Albania, though there are a number of research articles, ${ }^{50}$ and some publications by authors who do not make use of Italian sources. ${ }^{51}$ This last issue is a huge desideratum, as Albania was the only country occupied by Italy without German military aid, and where, in consequence, Italy was able to conduct its own policy without German encroachment. A clearer picture of Albania under Italian rule might serve to give us a 'pure model' of Italian imperialist policy, enabling a better understanding of the situation in other areas like Yugoslavia and Greece. Moreover in Albania, more than anywhere else, the Italian administrators had to come to terms with a traditional clan structure, and rely on it locally in order to exercise its own power. A case study on how this traditional society responded and adapted to foreign occupation would be very interesting.

Existing studies on Italian occupation in Greece tend to focus on war crimes and the role of the army; only a few look at the overall policy of the occupying power. A crucial but still unaccomplished task is to discover what factors in-

48 Cf. the essays collected in Francesco Caccamo / Luciano Monzali, eds, L'occupazione italiana della Iugoslavia (1941-1943), Florence 2008; Luciano Monzali, Antonio Tacconi e la comunità italiana di Spalato, Venezia 2007.

49 Luca Micheletta, La resa dei conti. Il Kosovo, l'Italia e la dissoluzione della Jugoslavia (1939-1941), Roma 2008.

50 Most of these are by the Italian historian Giovanni Villari. Cf. Giovanni Villari, L'Albania tra protettorato ed occupazione (1935-1943), Qualestoria 30, no. 1 (2002), 117-127; Giovanni Villari, A Failed Experiment. The Exportation of Fascism to Albania, Modern Italy 12, no. 2 (2007), 157-171; Giovanni Villari, Il sistema di occupazione fascista in Albania, in: Laura Brazzo / Michele Sarfatti, eds, Gli ebrei in Albania sotto il fascismo. Una storia da ricostruire, Firenze 2010, 93-124; Giovanni Villari, Repressione e resistenze in Albania, Qualestoria 43, no. 2 (2015), 81-97. Also Federico Niglia, Alleati, nemici, banditi, politica di occupazione e lotta alle 'bande' in Albania, Nuova Storia Contemporanea 16, no. 5 (2012), 47-64.

51 Bernd Jürgen Fischer, Albania at War, 1939-1945, West Lafayette/IN 1999; Hubert Neuwirth, Widerstand und Kollaboration in Albanien 1939-1944, Wiesbaden 2008. 
fluenced the dynamics of violence in the areas of Greece which Italy occupied. Greek scholars have recently stressed the importance of a food supply crisis, of internal conflicts within the occupied society in multiethnic areas, and of the collapse of the state. ${ }^{52}$ Increased cooperation between Italian and Greek scholars might be of great value here. It would be good to forge a stronger link between their respective national historiographies, which have so far developed in separate ways.

There are still too few overviews of Italian war aims and plans for postwar reshaping of the occupied regions. Although Italian goals in the Balkans were never elaborated to the extent that Nazi Germany's were in some of the regions it occupied, the subject would merit more in-depth analysis. There is a huge gap in our knowledge concerning economic aspects of the occupation. As yet, only a handful of scholars have conducted research in this field. ${ }^{53}$ It is established that Germany had the lion's share in exploiting the Balkan area, ${ }^{54}$ but we do not have a clear picture of the economic relations between Italy and its occupied regions during the war. To which extent did Italy exploit these regions to strengthen its own weak war economy, following the example of Germany? ${ }^{55}$ How did Italian occupation impact on local economies, and how did economic developments influence the spread of violence in the occupied regions?

A further shortcoming in studies of Italian occupation is related to the sources most of them employ. An overemphasis on Italian sources and Italian secondary literature is still prevalent and leads many scholars to part-identify with the perspectives of their sources. Often the result is scholarship that remains too firmly entrenched in debates surrounding the interpretation of Italian history, and at risk of reproducing the colonial outlook of the occupiers. It would certainly help scholars overcome this limitation if they made greater use of local sources and drew on documents of different provenance. German sources are of particular importance. Disregard of these prevents historians from getting a clear picture of the intentions and policies of the various German agencies also involved in occupation. In Italian writing, the German occupation authorities are often simplistically referred to as 'the German ally', overlooking the fact that German decision-making, it is now generally acknowledged, had a polycratic

52 See Nikos Maratzidis / Georgios Antoniou, The Axis Occupation and Civil War. Changing Trends in Greek Historiography, 1941-2002, Journal of Peace Research 41, no. 2 (2004), 223-231; and Polymeris Voglis' and Ioannis Nioutsikos' contribution to this issue.

53 See Alessandro Roselli, Italia e Albania. Relazioni finanziarie nel ventennio fascista, Bologna 1986 (English edition, Italy and Albania. Financial Relations in the Fascist Period, London et al. 2006); Rodogno, Nuovo ordine mediterraneo, 278-313; Goddi, Montenegro, 39-92.

${ }^{54}$ For comparison, cf. König, Kooperation als Machtkampf, 177-226.

55 For an overview of German economic policy in the occupied regions: Hein Klemann / Sergei Kudryashov, Occupied Economies. An Economic History of Nazi-Occupied Europe, 19391945, London, New York 2012. 
nature too. Moreover, the use of German sources could provide a refreshing 'external' view of Italian policy. Finally, it could help historians establish links and transfers between the two occupying regimes and draw systematic comparisons between them. ${ }^{56}$ As regards Italian sources, many remain unexplored and a dismaying number are inaccesible. In the first place, this is due to the chronic lack of financial resources in the Italian archival system, which has considerably worsened in the last ten years, making even officially accessible records practically unavailable. ${ }^{57}$ In addition, many institutions, wanting to keep a monopoly on interpretation, maintain an intentional policy of keeping important records out of the reach of researchers. ${ }^{58}$

Most scholarship on occupation during the war still gives overwhelming attention to the repressive policies that were practised. This is understandable, given the intense debate surrounding the issue; but even within this field there is a tendency to narrow the scope of research to anti-partisan warfare. This blocks out consideration of other instruments of repression employed by the occupying powers. Recent studies are bringing to light strategies of food denial, for example, which the occupation authorities used to force populations to succumb to their will. ${ }^{59}$ Issues still to be examined are the impact of such lower intensity repression on the occupied societies, and their reaction to it. The Italian occupation authorities used systematic internment as an instrument of repression against opponents, and also to achieve political or ethnic goals. Spartaco Capogreco, an Italian historian who has dedicated intensive research efforts to the internment of civilians in Fascist Italy, has calculated that 26,000 Montenegrins and 25,000 Slovenians were interned during the occupation. ${ }^{60}$ Other scholars have followed his lead. Basing her assessment on scattered sources, Alessandra Kersevan considers that a figure of approximately 100,000 internees from the zones of Yugoslavia under Italian rule would be not far off the mark. ${ }^{61}$ There are still no similar studies for Greece and Albania, although

56 How productive this field of research can be is demonstrated by Patrick Bernhard, Hitler's Africa in the East. Italian Colonialism as a Model for German Planning in Eastern Europe, Journal of Contemporary History 51, no. 1 (2015), 1-30.

57 For more information on this, see the internet page of the Italian Society for the Study of Contemporary History (SISSCO), http://www.sissco.it/articoli/documento-sissco-su-archivie-biblioteche-pubbliche/. All internet references were accessed on 19 March 2017.

58 A patent instance is the situation of the archives of the Military Ordinariate (Ordinariato Militare) that continues to deny access to external researchers.

59 Yannis Skalidakis, From Resistance to Counterstate. The Making of Revolutionary Power in the Liberated Zones of Occupied Greece, 1943-1944, Journal of Modern Greek Studies 33, no. 1 (2015), 155-184.

60 Carlo Spartaco Capogreco, Una storia rimossa dell'Italia fascista. L'internamento dei civili jugoslavi (1941-1943), Studi Storici 42, no. 1 (2001), 203-230.

61 Alessandra Kersevan, Lager italiani. Pulizia etnica e campi di concentramento fascisti per civili jugoslavi 1941-1943, Rome 2008, 102 and passim. 
we know that wide-ranging internment of civilians was practised in both regions. ${ }^{62}$ Opponents of the regime were detained not only in their own regions but were transferred en masse to Italy, where they were interned along with other categories of detainee and often employed in forced labour. The numbers involved suggest that internment may have impacted significantly on the occupied societies. However, there has been no attempt to deal with this topic systematically. ${ }^{63}$

A related question, still to be investigated, is whether, like Germany and many of its allies, Italy planned population transfers in its occupied regions, and, if so, to what extent. As far as we know, Italy did expel local populations from annexed regions like Dalmatia and Slovenia. ${ }^{64}$ Was there a plan for the ethnic reshaping of occupied regions for a settled postwar Italian empire? ${ }^{65}$ And was there continuity, in personnel or transfer of ideas, between the policy of ethnic homogeneization conducted during the interwar period in the 'new' northeastern provinces and policies implemented during the war? ${ }^{66}$ These last questions are particularly pertinent, as during World War II population transfer and ethnic engineering became common practice in Europe: there was a transnational culture of deportation shared by Germany, its allies, and the collaborationist elites of the occupied countries. ${ }^{67}$

62 First data in Rodogno, Nuovo ordine mediterraneo, 397-431. A group of young journalists has conducted an interesting project aimed at mapping all the places of internment in Italy and abroad, collecting sources on them and making them available to the public on an interactive map, http://www.campifascisti.it. The project achieved interesting results but it was suspended due to lack of funds.

${ }^{63}$ It is beyond the scope of this article to deal with the literature on Italian soldiers in German captivity - Italian military internees (Italienische Militärinternierte, IMI) - after the armistice of September 1943. Although there are relatively more studies on this topic than on the occupation, many blank spots remain in this area too. It is remarkable that the most comprehensive studies on this subject have been published by German historians, cf. Gerhard Schreiber, Die italienischen Militärinternierten im deutschen Machtbereich, 1943-1945. Verraten - verachtet - vergessen, München et al. 1990; Gabriele Hammermann, Zwangsarbeit für den 'Verbündeten'. Die Arbeits- und Lebensbedingungen der italienischen Militärinternierten in Deutschland 1943-1945, Tübingen 2002.

64 Rodogno, Nuovo ordine mediterraneo, 322-324.

65 An interesting instance is the plan developed by the Undersecretary for Albania (Sottosegretariato Albania) to create a common border between Albania and Romania, remove the Serb population from the border area and resettle it with Aromenians, cf. Micheletta, La resa dei conti, 117. A proposal for a population exchange between Albanians and Slavs was made by the Italian Lieutenant-General of the King in Albania, Francesco Jacomoni, in 1941, Goddi, Montenegro, 51.

66 Rolf Wörsdörfer, Krisenherd Adria 1915-1955. Konstruktion und Artikulation des Nationalen im italienisch-jugoslawischen Grenzraum, Paderborn 2004, 221-313.

${ }^{67}$ For an overview, Pertti Ahonen et al., People on the Move. Forced Population Movements in Europe in the Second World War and Its Aftermath, Oxford, New York 2008. 
A final field to be explored concerns the continuities that may have existed between the prewar colonial experience of military and administrative personnel-indeed of Italian society as a whole-and attitudes and practices maintained during the war itself. Several publications point to such continuities, and this is only to be expected since many military and civil servants had served in the colonies. But existing studies do not go beyond what, in 1992, Teodoro Sala called a 'colonial hypothesis'. ${ }^{68}$ Apart from a study of personnel continuities yet to be made, there is a need to investigate continuities in the cultural history of imperialism. Since Italian historiography has recently joined the international trend towards culturalization in studies of empire, ${ }^{69}$ it is surprising that nobody has tried to show if imperial imagery was at work in establishing and managing the occupation of the Balkan countries in the war years, and, if so, what its character was and what it may have owed to prewar experiences. This is all the more surprising since the 1936 Italian war against Ethiopia has recently attracted the interest of many historians, non-Italians among them. ${ }^{70}$

To sum up, many of the shortcomings I point out in this article have arisen because, in Italy, questions surrounding the history of occupation have long been treated as only an element in the study of Fascism - as Fascism in a particular setting. This narrowed approach is partly due to the fact that Italy has only a weak tradition of area studies on Southeastern Europe. It cannot compare with Germany, where Southeast European History is an established field with chairs at several universities, or the Anglo-Saxon world, which promotes Balkan Studies, nor with Southeastern Europe itself. A second reason lies in the severely delayed reception of international scholarship in Italian history faculties. ${ }^{71}$ These have been slow to take in recent literature on German occupation policy, which has started to shift its focus from national socialism to the occupied societies themselves. Moreover, continued harping on the 'good Italian versus bad Italian'

68 Teodoro Sala, Guerra e amministrazione in Jugoslavia 1941-1943: un'ipotesi coloniale, in: Bruna Micheletti / Pier Paolo Poggio, eds, L'Italia in guerra 1940-43, Brescia 1992. Further considerations on this can be found in Gobetti, Alleati del nemico, 92-93. The role of colonial experience in the formation of military personnel employed in Montenegro has been investigated in Goddi, Montenegro, 154-172.

69 Roberta Pergher, Impero immaginato, impero vissuto. Recenti sviluppi nella storiografia del colonialismo italiano, Ricerche di Storia Politica 10, no. 1 (2007), 53-66.

70 Aram Mattioli, eds, Der erste faschistische Vernichtungskrieg. Die italienische Aggression gegen Äthiopien 1935-1941, Luzern 2005; Giulia Brogini Künzi, Italien und der Abessinienkrieg 1935/36. Kolonialkrieg oder totaler Krieg?, Paderborn et al. 2006; Robert Mallett, Mussolini in Ethiopia, 1919-1935. The Origins of Fascist Italy's African War, New York 2015.

71 In a recent appraisal of the state of Italian contemporary history, Christof Dipper has criticized its low degree of internationalization, cf. Christof Dipper, Die italienische Zeitgeschichtsforschung. Eine Momentaufnahme, Vierteljahrshefte für Zeitgeschichte 63, no. 3 (2015), 351-378. Dipper's article will be discussed in the forthcoming issue of the journal Italia Contemporanea. 
theme (primarily an issue of national identity) has blinkered Italian historians and prevented them from developing a transnational approach. Though, in recent years, a new generation of scholars has brought important innovations to the field of occupation studies, there are still considerable gaps to fill.

\section{CORRESPONDING AUTHOR}

Paolo Fonzi Humboldt-Universität zu Berlin, Philosophische Fakultät I, Institut für Geschichtswissenschaften, Südosteuropäische Geschichte, Unter den Linden 6, 10099 Berlin, Germany.

E-mail: fonzipao@hu-berlin.de 